\title{
Correlating household second-hand smoke exposure and respiratory symptoms in school children
}

\section{Korelacija izmedju izloženosti pasivnom pušenju u kućnom okruženju i pojave respiratornih simptoma kod školske dece}

\author{
Branislava Matic ${ }^{1}$, Dragana Vujanovic ${ }^{2}$, Snezana \\ Dejanovic $^{1}$, Verica Jovanovic ${ }^{1}$, Nela Djonovic ${ }^{3}$ \\ 1. Institute of Public Health of Serbia, Belgrade, Serbia \\ 2. Faculty of Pharmacy, Belgrade University, Serbia \\ 3. Faculty of Medical Sciences, University of Kragujevac, Serbia
}

RECEIVED 15.07 .2017

ACCEPTED 15.11 .2017

\section{ABSTRACT}

Objective. Aim of this paper was to correlate exposure to household second-hand smoke and respiratory symptoms in participating school children, who are attending ten primary schools in Belgrade, Serbia.

Method. In order to determine correlation between second-hand smoke exposure at home and respiratory symptoms in primary school pupils, a comparative cross-sectional study has been conducted. The study was conducted in ten primary schools on 735 children, in 44 classrooms in Belgrade, Serbia. A standardized questionnaire was distributed to parents/caregivers, on child's respiratory health, socioeconomic status and parents' lifestyle habits, primarily cigarette smoking.

Results. $78 \%$ of all exposed children have parents smoking up to 20 cigarettes/day, while more than $22 \%$ are exposed to parents' household second-hand smoke of more than 21 cigarettes per day $(p<0.0001)$. Respiratory disorders appear in $45.9 \%$ of children exposed to domestic second-hand smoke (CI 1.04-1.89), asthmatic symptoms in 33.5\% (CI 0.94-1.78), while the least incidence of disorders is reported for continuous cough, which have lasted for 3 months (3.3\%, CI 0.44-2.36), wheezing after exercise (4.5\%, CI 0.38-1.41) and being awaken by wheezing in last 12 months (7.4\%, CI 0.89-3.28).

Conclusion. Univariate logistic regression analysis proved that parental smoking exposure is a statistically significant predictor for childhood respiratory simptoms' manifestation.

Key words: tobacco smoke pollution; child; signs and symptoms, respiratory.

\author{
Branislava Matić ${ }^{1}$, Dragana Vujanovićz , Snežana \\ Dejanović ${ }^{1}$, Verica Jovanović ${ }^{1}$, Nela Djonović 3 \\ 1. Institut za javno zdravlje Srbije, Beograd, Srbija \\ 2. Farmaceutski fakultet, Beogradski Univerzitet, Beograd, Srbija \\ 3. Fakultet medicinskih nauka Univerziteta u Kragujevcu, Kragujevac, Srbija
}

PRIMLJEN 15.07.2017.

PRIHVAĆEN 15.11.2017.

\section{APSTRAKT}

Cilj. Cilj ovog rada je uspostavljanje korelacije između izloženosti pasivnom pušenju u kućnom okruženju i pojave respiratornih simptoma kod dece koja pohađaju deset osnovnih škola u Beogradu, Srbija.

Metod. Istraživanje je sprovedeno po tipu komparativne studije preseka, u deset osnovnih škola, na uzorku od 735 dece, u 44 učionice, u Beogradu, Srbija. Roditelji$\mathrm{ma} /$ starateljima distribuiran je standardizovani upitnik, sa pitanjima o respiratornom zdravlju dece, socio-ekonomskom statusu i navikama roditelja, pre svega o pušenju cigareta.

Rezultati. 78\% dece koja su izložena duvanskom dimu ima roditelje koji puše do 20 cigareta/dan, dok je više od $22 \%$ izloženo duvanskom dimu od popušenih preko 21 cigareta/dan, od strane roditelja $(p<0,0001)$. Respiratorni poremećaji prisutni su kod $45,9 \%$ dece izložene pasivnom pušenju u kućnom okruženju (Cl 1.04-1.89), astmatični simptomi kod 33,5\% (Cl 0,94-1.,78), dok je najniža incidenca ovih poremećaja prijavljena u slučaju hroničnog kašlja, u trajanju od 3 meseca $(3,3 \%, \mathrm{Cl} 0,44-2,36)$, vizinga nakon fizičke aktivnosti $(4,5 \%, \mathrm{Cl} 0,38-1,41)$, kao i za slučaj buđenja usled viziga u poslednjih 12 meseci $(7,4 \%, \mathrm{Cl}$ 0,89-3,28).

Zaključak. Univarijantnom logističkom regresionom analizom dokazano je da je izloženost roditeljskom pušenju duvana statistički značajan prediktor za pojavu respiratornih simptoma kod dece.

Ključne reči: zagadjenje duvanskim dimom; dete; znaci i simptomi, respiratorni. 


\section{INTRODUCTION}

Second/hand smoke refers to mixture of side stream smoke and exhaled mainstream smoke which pollutes air at points where tobacco smoking is being performed.' To date, beyond 4,000 chemicals, comprising a combination of liquids, inhalable particles, and gases are identified in tobacco smoke. Among 4000 chemicals, more than 70 of them are recognized to cause, initiate or promote cancer., World Health Organization assess that around 1.3 billion people smoke. ${ }^{4}$ This number is predicted to increase in future due to continuous rise of smoking rates among youth, primarily among girls. ${ }^{5}$ According to the World Health Organization assessment, some half of the children in the world are exposed to environmental tobacco smoke (ETS), mostly in their homes. This caused substantial morbidity, potentially triggering development of asthma and exacerbating symptoms ${ }^{6-12}$ Children exposed to ETS are at an increased risk for lower respiratory infections, middle ear disease, more severe asthma, respiratory symptoms, slowed lung growth, and sudden infant death syndrome. ${ }^{13,14}$

\section{METHODS}

Within the international SEARCH1 project (School Environment and Respiratory Health in Children, 20072009), a cross-sectional study took place in ten primary schools in Belgrade, Serbia. Study was performed on a sample of total of 735 children, aged 7 to 11 years. According to the project's methodology, schools were chosen (sampled) to be with heterogeneous characteristics: half of them in environmentally more advantaged areas and half in less advantaged ones, especially concerning the proximity of busy traffic, while children were chosen randomly. ${ }^{15}$ Besides the school's environment impact on respiratory health, we also used the data on home environment, household exposure to second-hand smoke, particularly, obtained through a standardized questionnaire distributed to parents/caregivers of the participating children ( $N=735)$. Concerning home environment of children, key questions in our study were on the extent of exposure to ETS of children, number of cigarettes smoked by parents on daily basis, number of smokers in the household (mother, father, or both), as well as on the respiratory status of children. These questions included data on wheezing, cough, and diagnosis of asthma. ${ }^{15}$

\section{Statistical methodology}

In order to summarize baseline, demographic and clinical symptoms and characteristics, of two groups of schoolchildren (exposed and non-exposed), a descrip- tive statistics was used. Chi-square test was used for the comparison of categorical variables. For the comparison of continuous variables, an ANOVA-test, or Median test (for variables without normal distribution) were used. A significance of 0.05 was required. Odd ratios with the corresponding $95 \%$ confidence intervals $(\mathrm{Cl})$ were estimated. In order to determine the optimal cut off values of the daily smoked number of cigarettes in relation to the occurrence of respiratory disorders, ROC (Receiver Operating Characteristic) curve was used. For the estimation of predictor impact of ETS on health disorders in children, univariate logistic regression analysis (LRA) was used. Analyses were performed using SPSS for Windows version 22 (SPSS, Inc, Chicago, IL).

This study aimed to determine the prevalence of household ETS exposure in school children in Belgrade, Serbia, as well as the association between ETS exposure and respiratory symptoms among them.

\section{RESULTS}

This study has involved 735 students from 10 Belgrade primary schools, 364 (49.5\%) girls and $371(50.5 \%)$ boys. There is no statistically significant difference among exposed and non-exposed children, by age. Mean age of mothers of the participating children was from $38.93 \pm 5$ years for non-ETS exposed children to $37.42 \pm 5.57$ years for ETS exposed children. Mothers exposing their children to ETS at home are significantly younger than mothers taking care not to expose their offspring ( $p \leq 0.0001)$. Fathers' mean age ranged from $42.32 \pm 5.86$ years for non-ETS exposed children to $41.65 \pm 6.17$ years for ETS exposed children. Again, as in the case of mothers, fathers exposing their children to household ETS are much younger, with high statistical significance $(p \leq 0.013)$. (Table 1).

Table 1. Demographic data on children and parents

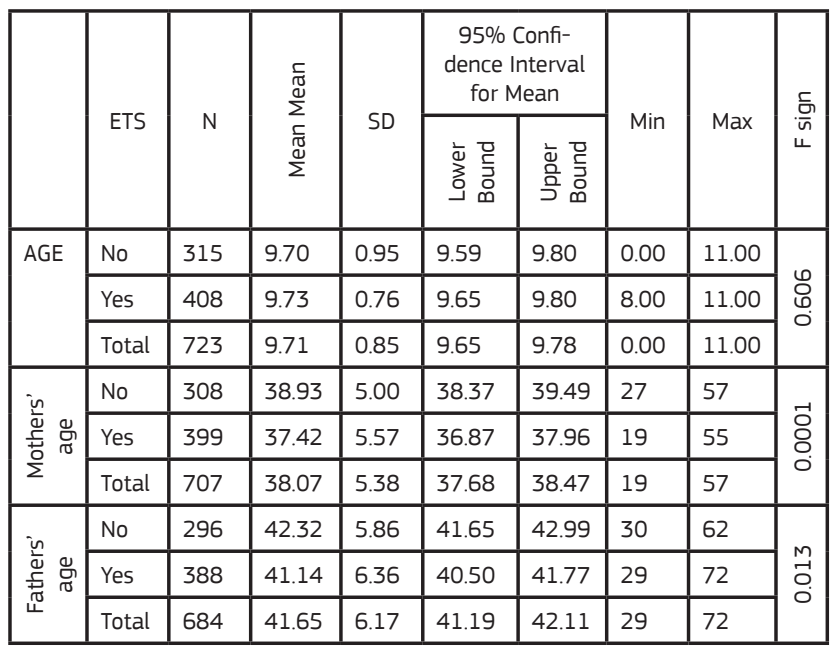


To household ETS 412 pupils were exposed (56.2\%), while the rest of them 321 (43.8\%) were not exposed to this indoor air pollutant. Parents of the participating children smoke from $7.65 \pm 11.25$ to $12.66 \pm 15.50$ cigarettes/ day (Table 2).

Table 2. Cigarettes/day smoked by parents correlated to household ETS of school children

\begin{tabular}{|c|c|c|c|c|c|c|c|c|}
\hline $\begin{array}{l}\text { Smoking } \\
\text { habits }\end{array}$ & \multicolumn{2}{|c|}{ Total } & \multicolumn{2}{|c|}{$\begin{array}{l}\text { Not exposed } \\
\text { to ETS }\end{array}$} & \multicolumn{2}{|c|}{$\begin{array}{c}\text { Household } \\
\text { ETS }\end{array}$} & \multirow[t]{2}{*}{$x^{2}$} & \multirow[t]{2}{*}{ sig } \\
\hline Mothers & $\mathrm{N}$ & $\%$ & $\mathrm{~N}$ & $\%$ & $\mathrm{~N}$ & $\%$ & & \\
\hline No smoking & 321 & 43.8 & 321 & 100.0 & 0 & 0.0 & & \multirow{4}{*}{$\overrightarrow{8}$} \\
\hline $\begin{array}{l}\text { Smoke 1-5/ } \\
\text { day }\end{array}$ & 68 & 9.3 & 0 & 0.0 & 68 & 100.0 & & \\
\hline Smoke $\geq 6$ /day & 344 & 46.9 & 0 & 0.0 & 344 & 100.0 & & \\
\hline Total & 733 & 100.0 & 321 & 43.8 & 412 & 56.2 & & \\
\hline Fathers & $\mathrm{N}$ & $\%$ & $\mathrm{~N}$ & $\%$ & $\mathrm{~N}$ & $\%$ & $x^{2}$ & sig \\
\hline No smoking & 321 & 43.8 & 321 & 100.0 & 0 & 0.0 & & \multirow{5}{*}{8} \\
\hline 1-10/day & 196 & 26.7 & 0 & 0.0 & 196 & 47.6 & & \\
\hline $11-20 /$ day & 124 & 16.9 & 0 & 0.0 & 124 & 30.1 & & \\
\hline$\geq 21 /$ day & 92 & 12.6 & 0 & 0.0 & 92 & 22.3 & & \\
\hline Total & 733 & 100.0 & 321 & 43.8 & 412 & 56.2 & & \\
\hline
\end{tabular}

Concerning the age distribution, no statistically significant difference among exposed and non-exposed children has been proven. As for their parents, both mothers $(p<0.0001)$ and fathers $(p<0.013)$ of children exposed to ETS at home are significantly younger than parents of nonexposed children. Number of cigarettes per day smoked by parents ranges from $7.65 \pm 11.25$ to $12.66 \pm 15.50$. As proved in this study, parents of most of the ETS exposed children smoke $\geq 6$ cigarettes/day $(p<0.0001)$. Namely, $78 \%$ of all exposed children have parents smoking up to 20 cigarettes/day, while more than $22 \%$ is exposed to parents' household second-hand smoke of more than 21 cigarettes per day $(p<0.0001)$.

Children exposed to tobacco smoke are more often prone to respiratory disorders, allergy and asthma diagnosis, as shown in Table 3.

Table 3. Symptoms and disorders correlated to household ETS of school children

\begin{tabular}{|c|c|c|c|c|c|c|c|c|c|c|c|}
\hline \multirow{3}{*}{ Respiratory symptoms } & \multicolumn{4}{|c|}{ Exposed to ETS } & \multicolumn{4}{|c|}{ Non-exposed to ETS } & \multirow{3}{*}{$\times 2$} & \multirow{3}{*}{$\underset{\cong}{\widehat{\underline{x}}}$} & \multirow{3}{*}{ (95\%) C.I. } \\
\hline & \multicolumn{2}{|c|}{ Yes } & \multicolumn{2}{|c|}{ No } & \multicolumn{2}{|c|}{ Yes } & \multicolumn{2}{|c|}{ No } & & & \\
\hline & $\mathrm{N}$ & $\%$ & $\mathrm{~N}$ & $\%$ & $\mathrm{~N}$ & $\%$ & $\mathrm{~N}$ & $\%$ & & & \\
\hline Cough ever & 95 & 23.7 & 306 & 76.3 & 63 & 20.1 & 251 & 79.9 & 1.346 & 1.237 & $0.86-1.77$ \\
\hline Morning cough (autumn/winter) & 45 & 11.3 & 355 & 88.7 & 32 & 10.2 & 282 & 89.8 & 0.205 & 1.117 & $0.69-1.80$ \\
\hline Cough day/ night, (autumn /winter) & 45 & 11.2 & 356 & 88.8 & 28 & 8.9 & 288 & 91.1 & 1.077 & 1.300 & $0.79-2.14$ \\
\hline Continuous cough 3 months (autumn/winter) & 13 & 3.3 & 384 & 96.7 & 10 & 3.2 & 302 & 96.8 & 0.003 & 1.022 & $0.44-2.36$ \\
\hline Phlegm & 39 & 9.7 & 362 & 90.3 & 30 & 9.6 & 284 & 90.4 & 0.006 & 1.020 & $0.62-1.68$ \\
\hline Wheezing ever & 96 & 23.6 & 310 & 76.4 & 58 & 18.6 & 253 & 81.4 & 2.606 & 1.351 & $0.94-1.95$ \\
\hline Dry cough last 12 months & 60 & 14.7 & 347 & 85.3 & 42 & 13.3 & 273 & 86.7 & 0.290 & 1.124 & $0.74-1.72$ \\
\hline Woken by wheezing in last 12 months & 30 & 7.4 & 375 & 92.6 & 14 & 4.5 & 299 & 95.5 & 2.643 & 1.709 & $0.89-3.28$ \\
\hline Ever Dg asthma & 55 & 13.5 & 351 & 86.5 & 39 & 12.5 & 272 & 87.5 & 0.157 & 1.093 & $0.70-1.70$ \\
\hline Asthma therapy /last 12 months & 39 & 9.6 & 368 & 90.4 & 29 & 9.3 & 282 & 90.7 & 0.014 & 1.031 & $0.62-1.52$ \\
\hline Allergy & 88 & 23.7 & 283 & 76.3 & 64 & 22.9 & 216 & 77.1 & 0.066 & 1.049 & $0.73-1.52$ \\
\hline Ever Dg allergy & 77 & 18.7 & 335 & 81.3 & 51 & 15.9 & 270 & 84.1 & 0.939 & 1.217 & $0.83-1.79$ \\
\hline Symptoms of bronchitis & 95 & 23.1 & 317 & 76.9 & 63 & 19.6 & 258 & 80.4 & 1.257 & 1.227 & $0.86-1.76$ \\
\hline Asthmatic symptoms & 138 & 33.5 & 274 & 66.5 & 90 & 28.0 & 231 & 72.0 & 2.508 & 1.293 & $0.94-1.78$ \\
\hline Respiratory disorders & 189 & 45.9 & 223 & 54.1 & 121 & 37.7 & 200 & 62.3 & 4.946 & 1.401 & $1.04-1.89$ \\
\hline
\end{tabular}

For a series of respiratory symptoms there is a higher probability to develop, than in children not exposed to ETS at home, in the following order: cough ever 12.7\%; morning cough in autumn/winter season 12.0\%; cough day and night in autumn/winter season $30 \%$; continuous cough during 3 months in autumn/winter season 2.2; continuous cough during 3 months in autumn/winter season, combined with phlegm $2.0 \%$; wheezing ever $35.1 \%$.
Development of the listed symptoms and disorders has a higher probability in ETS exposed children: "dry cough during 12 months", for 12.4\%; "awakened by wheezing during last 12 months", for 71\%; "cough ever combined with ever diagnosed asthma", for 9.3\%; "asthma therapy in last 12 months", for 3.1\%; "cough ever combined with ever diagnosed allergy", for 22\%; "ever diagnosed allergy", for $5 \%$. 
Number of school children being exposed to household ETS, acquiring respiratory disorders is proven to be more frequent, with high statistical significance $(p<0.026)$. For all of these symptoms and disorders linked mostly to coughing per se, exposure to household ETS is not a predictor (univariate logistic regression analysis), with no statistically significant difference in the distribution of participating pupils, compared to the symptoms or the exposure itself ( $x 2$ test).

Probability for "cough ever" to occur is $23.7 \%$ higher in children exposed to ETS (OR=1.237, CI 95\% 0.86-1.77); for "morning cough in autumn/winter season" it is $11.7 \%$ higher, (OR=1.117, Cl 95\% 0.69-1.80), "cough day and night in autumn/winter season" in ETS exposed subjects is 30\% higher, $(\mathrm{OR}=1.300, \mathrm{Cl} 95 \% 0.79-2.14)$; for "continuous cough for 3 months during autumn/winter season" in children exposed to ETS, chance to acquire it is only $2.2 \%$ higher, (OR=1.022, Cl 95\% 0.44-2.36); "wheezing ever" occurs with probability of $35 \%$ in ETS exposed children ( $O R=1.351, \mathrm{Cl} 95 \%$ 0.94-1.95). There is a higher probability for developing following symptoms and disorders in ETS exposed children: "dry cough during 12 months" (OR=1.124, Cl 95\% 0.74-1.72); "awakened by wheezing during last 12 months", (OR=1.709, Cl 95\% 0.89-3.28); "ever diagnosed asthma", (OR=1.093, Cl 95\% 0.70-1.70); "asthma therapy in last 12 months", (OR=1.031, Cl 95\% 0.62-1.52); "ever diagnosed allergy", (OR=1.217, Cl 95\% 0.83-1.79).; symptoms of bronchitis, (OR=1.227, $\mathrm{Cl} 95 \%$ 0.86-1.76); asthmatic symptoms (OR=1.293, Cl 95\% 0.941.78).

Exposure to ETS is a predictor for respiratory disorders. Namely, probability for the household second-hand smoke exposed children to acquire some of the respiratory disorders, analyzed in total, is $40 \%$ higher than in the case of ETS non-exposed children, participating in the study (OR=1.401, Cl 95\% $1.04-1.89$ ), $\mathrm{p}<0.023$.

Additional ROC analysis of sensitivity and specificity of the respiratory disorders' occurrence vs. the ETS exposure at home, in the form of the daily smoked number of cigarettes, proves that $\mathrm{ROC}$ curve covers a statistically significant area under the curve, $R O C=0.547 \pm 0.021, p<0.031$ (Graph 1, Table 4). In the case of school children exposed to household ETS, number of cigarettes smoked by parents daily $(>10)$ has statistically significant impact on the occurrence of respiratory disorders. This data is confirmed in results of the correlation in between ETS and respiratory symptoms of exposed children, presented in Table 3.

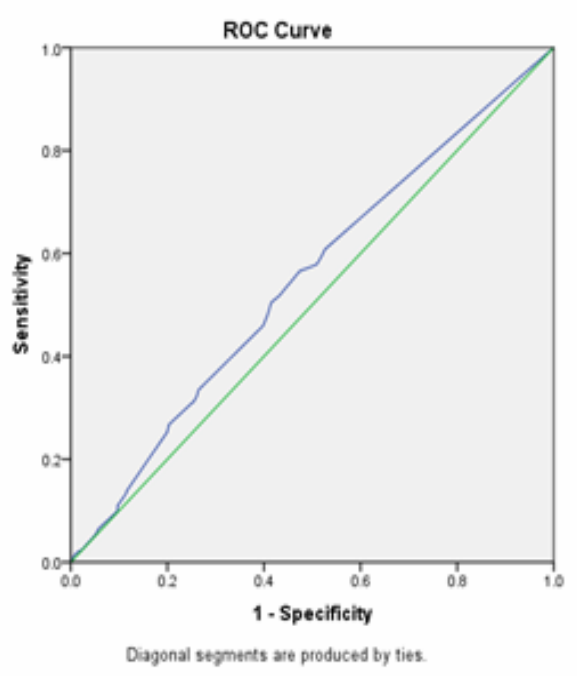

Graph 1. CiROC curve - respiratory disorders vs. number of cigarettes smoked by parents/day

Table 1. Elements defining the ROC curve

\begin{tabular}{|c|c|c|c|c|}
\hline \multicolumn{5}{|c|}{ Area Under the Curve } \\
\hline \multicolumn{5}{|c|}{ Test Result Variable(s): Number of cigarettes/day } \\
\hline \multirow{2}{*}{ Area } & \multirow{2}{*}{ Std. Error } & \multirow{2}{*}{$\begin{array}{l}\text { Asymptotic } \\
\text { Sig. }\end{array}$} & \multicolumn{2}{|c|}{$\begin{array}{l}\text { Asymptotic 95\% Confi- } \\
\text { dence Interval }\end{array}$} \\
\hline & & & $\begin{array}{l}\text { Lower } \\
\text { Bound }\end{array}$ & $\begin{array}{l}\text { Upper } \\
\text { Bound }\end{array}$ \\
\hline \multirow[t]{2}{*}{0.547} & 0.021 & 0.031 & \multirow{8}{*}{0.504} & \multirow{8}{*}{0.589} \\
\hline & \multicolumn{2}{|c|}{ Cut off values } & & \\
\hline Cut off & Sensitivity & Specificity & & \\
\hline 1.5 & $59.80 \%$ & $47.90 \%$ & & \\
\hline 6.5 & $50.50 \%$ & $58.50 \%$ & & \\
\hline 11 & $33.40 \%$ & $73.60 \%$ & & \\
\hline 15.5 & $26.70 \%$ & $79.70 \%$ & & \\
\hline 21 & $13.80 \%$ & $88.40 \%$ & & \\
\hline
\end{tabular}

ROC analysis of sensitivity and specificity shows that exposure to larger number of cigarettes per day is related with occurrence of respiratory symptoms in children, with statistical significance. For exposure to < 2 cigarettes/day, sensitivity for the occurrence of respiratory disorders is $60 \%$, specificity $47.9 \%$; for $>6$ cigarettes/day, sensitivity is $50.5 \%$ specificity $58,5 \%$; for exposure to $>10$ cigarettes/ day, sensitivity drops below 35\%, while for more than 15/ day sensitivity drops below $27 \%$ and specificity increases to $80 \%$, together with a rise in specificity beyond $88 \%$ for the occurrence of respiratory symptoms in the case children are exposed to ETS of $>20$ cigarettes/day. 


\section{DISCUSSION}

For better comprehension of the correlation between ETS and respiratory symptoms, it is important to be acquainted with other contributing factors. In their study, Oberg et al. indicated that exposure to ETS is among the most common indoor pollutants. ${ }^{16}$ While in our study household second-hand smoke of both parents complies with their smoking habits in $56.2 \%$ cases, in the Jordanian study out of $77 \%$ parents with smoking habits, them $61 \%$ practice it at home. ${ }^{17}$ According to the World Health Organization (WHO), over half of all children aged 13-15 years are exposed to household ETS in the majority of countries, for which comparable information is available. In the Balkans and the Caucasus, exposure is beyond $90 \% .{ }^{18}$ The Global Youth Tobacco Survey was implemented only in the Southern Europe Countries, the Balkans and Caucasus, together with the Baltic countries, for the period 2002-2005 (GYTS). In Serbia, 97\% of surveyed children were exposed to household ETS. ${ }^{19}$ When the same survey has been repeated in 2013, results showed a rather big improvement, with $63.4 \%$ surveyed children responding positively as being exposed to ETS at home..$^{20} \mathrm{As}$ for other kinds of chemical substance exposures in school environment, fact is that most of the urban schools in Serbia were built and equipped by uniform standards, given in the Rulebook defining standards for the school environment, equipment and educational utensils in primary schools. ${ }^{21}$

In conclusion, univariate logistic regression analysis has proved that exposure to ETS is a statistically significant predictor for respiratory symptoms' occurrence. In this survey, chances that children who are exposed to household ETS have manifested any of listed respiratory symptoms are $40 \%$ higher than in the children not exposed to ETS in their home.

Until now, Serbian legal system has recognized only second-hand exposure to ETS in institutional facilities, public spaces, such as shopping areas, educational premises, offices, while there is no legal act dealing with living conditions within the private property, such as homes, apartments, and other locations where children could be exposed to environmental tobacco smoke..$^{22}$ Finally, Serbia has legally adopted Children's Environmental Health Action Plan for 2010 - 2019, which was never to be implemented in practice. ${ }^{23}$

\section{ACKNOWLEDGMENTS}

The financial support for the SEARCH1 project by the Italian Ministry for the Environment, Land and Sea is highly appreciated by the authors.

\section{REFERENCES}

1. Samet JM. Workshop summary: Assessing exposure to environmental tobacco smoke in the workplace. Environ Health Perspect 1999; 107 (Suppl.2): 309-12.

2. How Tobacco Smoke Causes Disease: The Biology and Behavioral Basis for Smoking-Attributable Disease. A Report of the Surgeon General. Centers for Disease Control and Prevention (US); National Center for Chronic Disease Prevention and Health Promotion (US); Office on Smoking and Health (US). Atlanta (GA): Centers for Disease Control and Prevention (US), 2010.

3. Hecht SS. Research opportunities related to establishing standards for tobacco products under the family smoking prevention and tobacco control act. Nicotine Tob Res 2012; 14: 18-28.

4. Brower V: World Health Organization focuses on antitobacco efforts in developing nations through treaty. J Natl Cancer Inst 2006; 98: 667-8.

5. Warren CW, Jones NR, Peruga A, Chauvin J, Baptiste JP, Costa de Silva V, et al. Global youth tobacco surveillance, 2000-2007. MMWR Surveill Summ 2008; 57: 1-28.

6. Beasley R, Crane J, Lai CK, Pearce N. Prevalence and etiology of asthma. J Allergy Clin Immunol 2000; 105(2 Pt 2): S466-72.

7. Cook DG, Strachan DP. Health effects of passive smoking. 3. Parental smoking and prevalence of respiratory symptoms and asthma in school age children. Thorax 1997; 52: 1081-94.

8. Gilliland FD, Berhane K, Islam T, Wenten M, RappaportE, Avol E, et al. Environmental tobacco smoke and absenteeism related to respiratory illness in schoolchildren. Am J Epidemiol 2003; 157: 861-9.

9. Gilliland FD, Li YF, Peters JM. Effects of maternal smoking during pregnancy and environmental tobacco smoke on asthma and wheezing in children. Am J Respir Crit Care Med 2001; 163: 429-36.

10. Martinez FD, Cline M, Burrows B. Increased incidence of asthma in children of smoking mothers. Pediatrics 1992; 89: 21-6.

11. Rushton L, Courage C, Green E. Estimation of the impact on children's health of environmental tobacco smoke in England and Wales. J R Soc Promot Health 2003; 123: $175-80$. 
12. Cabana MD, Birk NA, Slish KK, Yoon EY, Pace K, Nan, et al. Exposure to Tobacco Smoke and Chronic Asthma Symptoms. Pediatr Asthma Allergy Immunol 2005; 18: 180-8.

13. Moritsugu KP. The 2006 Report of the Surgeon General: the health consequences of involuntary exposure to tobacco smoke. Am J Prev Med 2007; 32: 542-3.

14. Mannino DM, Siegel M, Husten C, Rose D, Etzel R. Environmental tobacco smoke exposure and health effects in children: results from the 1991 National Health Interview Survey. Tob Control 1996; 5: 13-8.

15. Eva Csobod E, Peter Rudnai P, Vaskovi E, eds. School Environment and Respiratory Health of Children (SEARCH ). International research project report within the "Indoor air quality in European schools: Preventing and reducing respiratory diseases program". Szentendre, 2010. (http:// search.rec.org/search1/doc/SEARCH\%20publication_ EN_final.pdf)

16. Oberg $M$, Jaakkola $M$, Woodward A, Perug A, Prüssüstun A. Worldwide burden of disease from exposure to second-hand smoke; Retrospective analysis of data from 192 countries. Lancet 2011; 337: 139-46.

17. AL Ali N, Alhamdan Z, Almughrabi N. The health consequences of second-hand smoke exposure on asthma and respiratory health of school children in Jordan. Nursing and Health 2015; 3: 39-46.

18. World Health Organization. Exposure of children to second-hand tobacco smoke. Factsheet 3.4; Geneva: World Health Organization, 2009. (http://www.euro.who. int/__data/assets/pdf_file/0020/97004/3.4-Exposureof-children-to-second-hand-smoke-EDITED_layouted. pdf?ua=1)

19. World Health Organization. Tobacco Free Initiative (TFI). Global youth tobacco survey (GYTS). Geneva: World Health Organization, 2017. (http://www.who.int/tobacco/surveillance/gyts/en/)

20. Serbia 2013 Country Report, Global Youth Tobacco Survey (GYTS). Belgrade: Ministry of Health of the Republic of Serbia, Institute of Public Health of Serbia, 2014. (http://www.batut.org.rs/download/publikacije/2014gyt sSerbiaReport.pdf)

21. Rulebook on the standards for the school environment, equipment and educational means for primary schools. Belgrade: Official Gazette of the SRS - Education- al Gazette No. 4/90, 1990. (in Serbian).

22. Law on protection from exposure to tobacco smoke. Belgrade: Official Gazette RS, No. 30/2010, 2010. (in Serbian).

23. Children's Environmental Health Action Plan for 2010 - 2019. Belgrade: Official Gazette RS, No. 83/09, 2009. (in Serbian). 